\title{
Aethotaxis mitopteryx, a high-Antarctic fish with benthopelagic mode of life
}

\author{
Andreas Kunzmann, Christopher Zimmermann \\ Institute for Polar Ecology, Wischhofstr. 1-3, W-2300 Kiel 14, Germany
}

\begin{abstract}
Aethotaxis mitopteryx DeWitt is one of the lesser known high-Antarctic fish species of the family Nototheniidae. Within the last 7 yr close to $90 \%$ of all reported specimens were caught in the Weddell Sea and the Lazarev Sea, with only $5 \%$ of these in pelagic trawls. Average biomass values of ca $0.69 \mathrm{~kg} 30 \mathrm{~min}^{-1}$, which is 10 times the biomass values attained in the Weddell Sea, suggest the Lazarev Sea at depths between 400 and $800 \mathrm{~m}$, or narrow shelf areas of the eastern Antarctic in general, to be a major distribution area of this species. Due to new maximum values reported for length and weight (total length $=48 \mathrm{~cm}$, fresh weigth $=855 \mathrm{~g}$ ) currently recorded growth parameters have to be adjusted. Adults are characterized by slow growth, high reproductive effort, a benthopelagic mode of life and regular occurrence in the warmer deep water. Due to the high abundance of $A$. mitopteryx larvae in the Weddell Sea, spawning migrations are likely. Structural and functional features of blood as well as observations from aquaria indicate a sluggish mode of life and a limited scope for activity. This and number of adaptations to life in the pelagial suggest energy requirements to be low.
\end{abstract}

\section{INTRODUCTION}

The high-Antarctic shelf seas are characterized by particularly low and constant temperatures $(-1.6$ to $-2.1^{\circ} \mathrm{C}$ ), high oxygen contents of more than $95 \%$ saturation (Hellmer \& Bersch 1985) and an extreme seasonality of ice conditions and pelagic production. In addition, in the Weddell Sea a complex system of currents and a characteristic distribution of water masses on the shelf are found (Hubold 1992). Hydrographical isolation and constant low temperatures have led to a high degree of stenothermy and endemism in the Antarctic fish fauna (DeVries \& Eastman 1981).

Compared to the rest of the Antarctic fish fauna, members of one tribe, the Pleuragrammiini (Andersen 1984), were discovered relatively late: Pleuragramma antarcticum (1902), Aethotaxis mitopteryx (1962), Cryothenia peninsulae (1981), and Gvozdarus svetovidovi (1989). All 4 species are more or less confined to a pelagic mode of life, and apart from $P$. antarcticum they have only been caught in very low numbers.

Aethotaxis mitopteryx was first described by DeWitt (1962) from 1 holotype taken from McMurdo Sound. It was assumed to have a pelagic lifestyle, and that the continental slope was its major habitat (DeWitt 1970). Between 1962 and 1982 only a few specimens of A. mitopteryx were recorded (total of 9 specimens), mainly by Soviet authors (see Table 2). Hureau \& Fischer (1985) and Gon \& Heemstra (1990) summarize the knowledge on the ecology of $A$. mitopteryx as follows: It is a pelagic species known to a depth of $850 \mathrm{~m}$, with an apparently circum-Antarctic distribution. It feeds on small zooplankton (krill, copepods, pelagic amphipods). Buoyancy is provided by the storage of lipids in cells of adipose tissue and by reduced calcification of the skeleton (DeVries \& Eastman 1981). The maximum size (total length) is reported to be $42 \mathrm{~cm}$.

The mode of life and the ecology of fishes are correlated with the haematology and the structure and function of their haemoglobins (Riggs 1970 , Coburn \& Fischer 1973, Love 1980, Wells et al. 1989). A variety of adaptations in the oxygen transport system of Antarctic fishes have developed as a consequence of the slow but progressive cooling of their environment since the Tertiary. Blood parameters, such as haematocrit, number of red blood cells and haemoglobin concentrations, are reduced in all endemic fish species in Antarctica (Wells et al. 1980) 
and decrease in the order Nototheniidae, Artedidraconidae, Bathydraconidae, and Channichthyidae (Kunzmann 1991).

In addition, the number of different haemoglobins, which is usually multiple in temperate fishes (Love 1980), is reduced in Antarctic fishes from $\geq 2$ in nototheniids to 1 in artedidraconids and bathydraconids, and to 0 in channichthyids (Kunzmann \& di Prisco 1990). These findings reflect the phylogeny of endemic Antarctic fish families.

The present paper presents biological information about Aethotaxis mitopteryx from a number of Antarctic expeditions with RV 'Polarstern' during the last 7 yr. Major emphasis is placed on the ecology, fisheries biology and blood physiology of the species in an attempt to establish a hypothesis concerning its mode of life.

\section{MATERIAL AND METHODS}

Aethotaxis mitopteryx were caught by various nonclosing nets (Table 1) during the following cruises of RV 'Polarstern' in the eastern and southeastern Weddell Sea and the Lazarev Sea: ANT III/3 (Jan to Mar 1985), ANT VII/4 (Jan to Mar 1989), ANT IX/3 (Jan to Mar 1991), ANT X/3 (Mar to May 1992). Exact positions and depths of all hauls are given in the respective cruise reports (Hempel 1985, Schnack-Schiel 1987. Hureau et al. 1990, Wöhrmann \& Zimmermann 1992, di Prisco et al. in press).

The fish were usually sorted, counted, measured, weighed and frozen at $-30^{\circ} \mathrm{C}$ or fixed in formalin immediately after the catch. Stomachs and gonads were dissected and fixed in $4 \%$ buffered formalin. Total length (TL), standard length (SL) and weight (fresh weight, FW; and gutted weight, GW) measurements were rounded down to the next $\mathrm{cm}$ and $\mathrm{g}$, respectively. Sex and maturity stage were identified according to Everson (1977). Stomach content was analyzed after estimating the degree of stomach fullness

Blood samples were drawn from the caudal vein of unanaesthetized specimens by means of heparinized syringes. The general blood parameters were investigated immediately on board the 'Polarstern' and comprised:
$\mathrm{pH}, \mathrm{PO}_{2}$ and $\mathrm{PCO}_{2}$ (partial pressure of oxygen and carbon dioxide), measured with an 'Eschweiler' blood gas analyzer system 2000 ;

- RBC (number of red blood cells), measured with a 'Sysmex' CC-108 cell counter;

- Hct (haematocrit), [Hb] (haemoglobin concentration), $\mathrm{MCH}$ (mean cellular haemoglobin) and MCHC (mean corpuscular haemoglobin concentration), which were determined using standard techniques (Coburn \& Fischer 1973, Hallmann 1980).

A detailed description of all methods is given by Kunzmann (1991).

\section{RESULTS}

\section{General biology}

During the 4 'Polarstern' expeditions between 1985 and 1992 a total of 99 Aethotaxis mitopteryx specimens were caught in the Weddell and Lazarev Seas. This represents $90 \%$ of all reported (112) specimens caught so far (Table 2). More than $50 \%$ of these were caught in the Lazarev Sea during ANT IX/3 (1991). Also, the largest number of specimens per single haul was obtained during this cruise (19 specimens; bottom trawl Stn $174 ; 69^{\circ} 43.7^{\prime} \mathrm{S}, 10^{\circ} 44.7^{\prime}$ E, $430 \mathrm{~m}$ depth).

From these 99 specimens 65 were caught in the bottom trawl, 25 in the Agassiz trawl and only 9 in pelagic trawls (krill net and benthopelagic trawl). Fifty-five specimens were caught at depths between 400 and $700 \mathrm{~m}$ and 42 specimens at depths of more than $700 \mathrm{~m}$. Table 3 shows the total number of hauls performed with each gear type on all 'Polarstern' cruises between 1985 and 1992 and emphasizes the fact that, although there were only 24 hauls in the Lazarev Sea, they yielded more specimens of Aethotaxis mitopteryx than 182 hauls from the Weddell Sea.

In summer in the Lazarev Sea $40 \%$ of all Aethotaxis mitopteryx were females at maturity stages between I and IV, and $60 \%$ were males at maturity stages between I and III (Table 4). Most specimens were at maturity stage II. There was no significant correlation between maturity and depth.

Table 1 Types and sizes of nets used for fish catches during various Antarctic expeditions of RV 'Polarstern'

\begin{tabular}{|c|c|c|c|c|}
\hline Name & Net type & $\begin{array}{l}\text { Mouth opening } \\
\text { (Width } \times \text { height }{ }_{i} \text { ) }\end{array}$ & $\begin{array}{c}\text { Tow velocity } \\
\text { (nautical miles } \mathrm{h}^{-1} \text { ) }\end{array}$ & Source \\
\hline Agassiz trawl & Epibenthic sledge & $3 \times 1$ & $0.5-1.5$ & Ekau (1988) \\
\hline Krill net & Holopelagic gear & $10 \times 10$ & 4.0 & Hubold \& Ekau (1987) \\
\hline Bottom trawl & Commercial benthic heavy gear & $22 \times 5$ & $3.0-4.0$ & Ekau (1988) \\
\hline Bentho-pelagic trawl & Semipelagic gear & $18 \times 18$ & $3.0-4.5$ & Hureau et al. (1990) \\
\hline
\end{tabular}


Table 2. Catches of adult Aethotaxis mitopteryx. " Weddell Sea; ANT: cruise number and leg of Antarctic expedition of RV 'Polarstern'; AGT: Agassiz trawl; BT bottom trawl; BPT: bentho-pelagic trawl; KN: krill net

\begin{tabular}{|c|c|c|c|c|c|}
\hline $\mathrm{n}$ & Location & Depth $(\mathrm{m})$ & Net & Date & Source \\
\hline 1 & Ross Sea/McMurdo Sound & 0 & & Nov 1960 & DeWitt (1962) \\
\hline 2 & South Orkney Isl. & $?$ & $?$ & 1965 & Permitin (1966) (cited after Kotlyar 1979) \\
\hline 1 & South Sandwich lsl. & 685 & BT & Mar 1967 & Permitin (1969) \\
\hline 1 & Gunnerus Bank & $?$ & BT & Feb 1973 & Gerasimchuk \& Piotrovskiy (1981) \\
\hline 1 & South Shetland Isl. & 800 & $\mathrm{BT}$ & Feb 1975 & Kotlyar (1979) \\
\hline 1 & Prydz Bay & 420 & $\mathrm{BT} ?$ & Mar 1978 & Gerasimchuk \& Piotrovskiy (1981) \\
\hline 1 & $\begin{array}{l}\text { South Sandwich } \\
\text { or South Georgia }\end{array}$ & $?$ & $?$ & $?$ & Townsend (1980) \\
\hline$\geq 1$ & Lazarev Sea & $?$ & $?$ & 1981 & Trunov (1985) \\
\hline$\geq 1$ & North of South Shetlands & $?$ & BT & $1982 ?$ & Takahashi (1982) \\
\hline 2 & Gould Bay" & 667 & $\mathrm{BT}$ & $\mathrm{Jan} / \mathrm{Feb} 1985$ & ANT III/3 \\
\hline 1 & Kap Norvegia ${ }^{*}$ & $0-400$ & $\mathrm{KN}$ & $\mathrm{Jan} / \mathrm{Feb} 1985$ & ANT III/3 \\
\hline 6 & Vahsel Bay* & 1145 & AGT & $\mathrm{Jan} /$ Feb 1985 & ANT III/3 \\
\hline 1 & Vahsel Bay & $0-680$ & $\mathrm{KN}$ & Jan/Feb 1985 & ANT III/3 \\
\hline 12 & Vestkapp ' & 984 & AGT & Jan/Feb 1985 & ANT III/3 \\
\hline 3 & Vestkapp & 423 & BT & Jan/Feb 1985 & ANT III/3 \\
\hline 1 & South Georgia & $?$ & $\mathrm{BT}$ & Feb 1985 & $\begin{array}{l}\text { K.-H. Kock, Institut für Seefischerei, } \\
\text { Palmaille 9, W-2000 Hamburg, Germany, } \\
\text { pers. comm. }\end{array}$ \\
\hline 2 & Prydz Bay & 750 & $?$ & Feb 1987 & Williams $(1987)$ \\
\hline 1 & Halley Bay & 516 & BT & Feb/Mar 1989 & ANT VIL/4 \\
\hline 1 & North of Halley Bay ${ }^{*}$ & 483 & AGT & Feb/Mar 1989 & ANT VIL/4 \\
\hline 2 & North of Halley Bay & 699 & AGT & Feb/Mar 1989 & ANT VIL/4 \\
\hline 3 & North of Halley Bay. & 799 & BPN & Feb/Mar 1989 & ANT VII/4 \\
\hline 1 & North of Halley Bay & 602 & BT & Feb/Mar 1989 & ANT VII/4 \\
\hline 6 & North of Halley Bay & 796 & $\mathrm{BT}$ & Feb/Mar 1989 & ANT VII/4 \\
\hline 1 & South of Kap Norvegia & 402 & $\mathrm{BT}$ & Feb/Mar 1989 & ANT VII/4 \\
\hline 1 & Lazarev Sea & 440 & AGT & Feb 1991 & ANT IX/3 \\
\hline 1 & Lazarev Sea & 880 & AGT & Feb 1991 & ANT IX/3 \\
\hline 1 & Lazarev Sea & 750 & $\mathrm{AGT}$ & Feb 1991 & ANT $I X / 3$ \\
\hline 12 & Lazarev Sea & 800 & $\mathrm{BT}$ & Feb 1991 & ANT IX/3 \\
\hline 10 & Lazarev Sea & 510 & BT & Feb 1991 & ANT IX/3 \\
\hline 19 & Lazarev Sea & 430 & BT & Feb 1991 & ANT IX/3 \\
\hline 10 & Lazarev Sea & 660 & $\mathrm{BT}$ & Mar 1991 & ANT IX/3 \\
\hline 1 & Lazarev Sea & 780 & AGT & Apr 1992 & ANT $X / 3$ \\
\hline 4 & Kap Norvegia & 600 & $\mathrm{BPT}$ & May 1992 & ANT $X / 3$ \\
\hline
\end{tabular}

Table 3. Total number of net hauls made for 4 gear types during 'Polarstern' cruises ANT 1 to ANT X (1980 to 1992)

\begin{tabular}{|lrrrc|}
\hline \multirow{2}{*}{ Area } & \multicolumn{4}{c|}{ Net type } \\
& BT & AGT & KN & BPT \\
\hline Weddell Sea & 41 & 115 & 18 & 8 \\
Lazarev Sea & 5 & 18 & 0 & 1 \\
\hline
\end{tabular}

Table 4. Aethotaxis mitopteryx. Maturity stages (February 1991; Lazarev Sea) according to the Everson scale; $\mathrm{n}=33$

\begin{tabular}{|c|c|c|c|c|}
\hline \multirow[t]{2}{*}{ Sex } & \multicolumn{4}{|c|}{ Stage } \\
\hline & I & II & III & IV \\
\hline Male & 5 & 10 & 5 & 0 \\
\hline Female & 3 & 5 & 3 & 2 \\
\hline
\end{tabular}

Stomach content analysis yielded $70 \%$ empty, $23 \%$ slightly full and only $6 \%$ rather full stomachs. The only taxa which could be identified were 2 gammarid amphipods from 2 stomachs.

TL, SL and FW of adults from the Lazarev Sea ranged from 9 to $48 \mathrm{~cm}, 7$ to $42 \mathrm{~cm}$ and 76 to $850 \mathrm{~g}$, respectively. The length frequency distribution shows 2 peaks around $24-25 \mathrm{~cm}$ and around $27-28 \mathrm{~cm}$ (Fig. 1). No relationship between length and depth could be established (Fig. 2)

Fig. 3 presents the length/weight relationship for both FW and GW of all Lazarev Sea specimens. Regression curves were fitted according to the equation FW $(\mathrm{GW})=a \mathrm{SL}^{b}$. The regression coefficient a and the exponent $b$ for FW (GW) were calculated to be $0.022(0.007)$ and 2.74 (3.06), with a correlation coefficient of $0.975(0.995)$. A comparison with the 


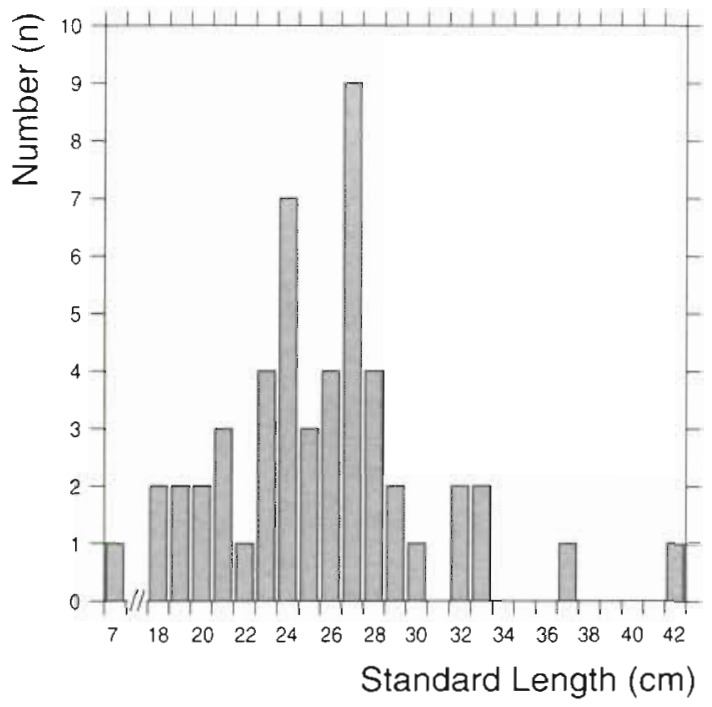

Fig. 1. Aethotaxis mitopteryx. Length frequency data of specimens caught during ANT IX/3 in the Lazarev Sea

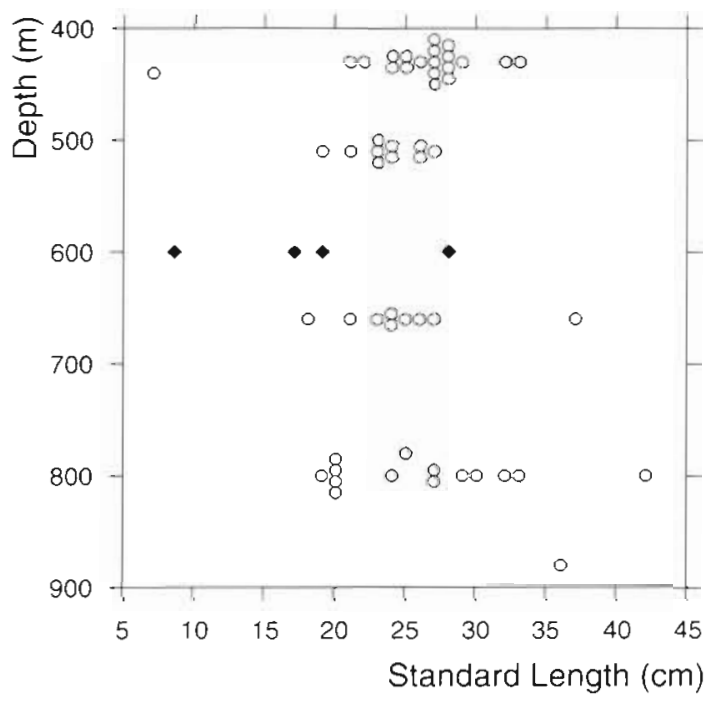

Fig. 2. Aethotaxis mitopteryx. Standard length of specimens from ANT IX and ANT X, plotted versus depth. (0) Lazarev Sea specimens; $(\bullet$ Weddel]. Sea specimens. No significant correlation was found

Weddell Sea data from Ekau (1988) shows the larger Weddell Sea specimens to be in slightly better condition (Fig. 3).

Measurements of the otolith length (OL) and weight (OW) of 10 specimens from the Lazarev Sea are presented in Table 5. The relationship of OL to SL is almost linear, and when a straight line is fitted we obtain the equation $\mathrm{OL}=0.17+0.014 \mathrm{SL}(\mathrm{r}=0.874$, $n=10$ ), in good agreement with data from Hecht (1987)

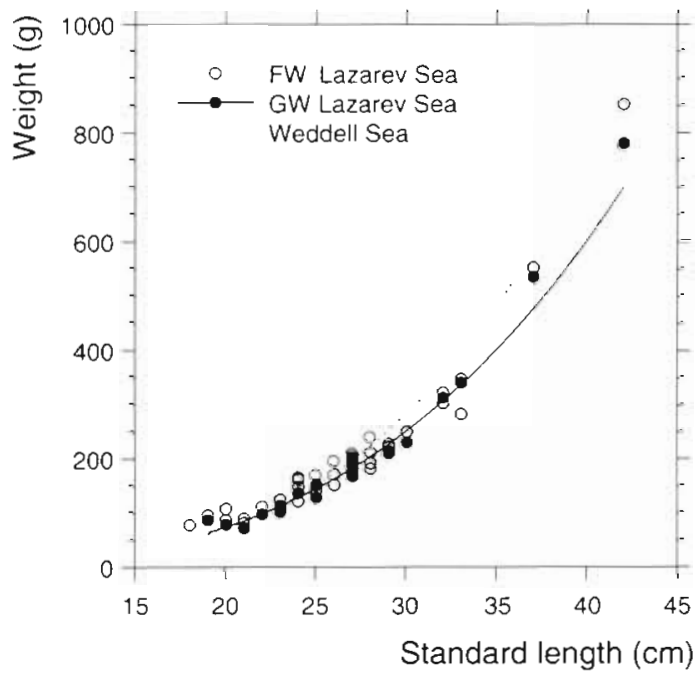

Fig. 3. Aethotaxis mitopteryx. Length-weight relationship. FW: fresh weight; GW: gutted weight. Weddell Sea data are from Ekau (1988). For regression analysis see text

\section{Morphology}

Fig. 4 is a drawing of an adult Aethotaxis mitopteryx specimen of more than $35 \mathrm{~cm}$ standard length which is based on observations of several different specimens and on live observations in aquaria. In the following paragraph we do not pre. sent a general and complete description of the species but rather emphasize some morphological features which have not previously been presented in the literature.

The shape of the body seems to be more streamlined at older ages when compared with the drawings of younger specimens in Hureau \& Fischer (1985) and Gon \& Heemstra (1990). The peduncle of the caudal fin is slender. The pectoral fins are very motile and delicate. In the aquaria the species never moves with the caudal fin, but steadily undulates the pectoral fins in an arc of almost $180^{\circ}$. The pelvic fins are soft and the species has never been observed 'sitting' on them.

\section{Blood physiology}

Table 6 shows the most important blood parameters of Aethotaxis mitopteryx. Blood viscosity is clearly reduced in $A$. mitopteryx, due to a low haematocrit $(14.0 \%)$ and a low number of red blood cells $(0.39 \times$ $10^{12} \mathrm{l}^{-1}$ ). The haematocrit of other Antarctic fishes is reported to be 19 to $38 \%$ (Kooyman 1963, Everson \& Ralph 1968). 
Table 5. Aethotaxis mitopteryx. Dimensions of otoliths from Lazarev Sea specimens. SL: standard length; GW: gutted weight; OL: otolith length; OW: otolith weight. Pairs of values for $O L$ and $O W$ are for both otoliths of 1 specimen

\begin{tabular}{|c|c|c|c|c|c|c|c|}
\hline \multirow{2}{*}{$\begin{array}{c}\begin{array}{c}\mathrm{SL} \\
(\mathrm{cm})\end{array} \\
19\end{array}$} & \multirow{2}{*}{$\begin{array}{l}\text { GW } \\
\text { (g) } \\
85\end{array}$} & \multirow{2}{*}{$\begin{array}{l}\text { Sex } \\
\text { Male }\end{array}$} & \multirow{2}{*}{$\begin{array}{c}\text { Maturity } \\
\text { stage } \\
\text { I }\end{array}$} & \multicolumn{2}{|c|}{$\begin{array}{c}\mathrm{OL} \\
(\mathrm{cm})\end{array}$} & \multicolumn{2}{|c|}{$\begin{array}{l}\text { OW } \\
\text { (g) }\end{array}$} \\
\hline & & & & 0.336 & 0.342 & 0.014 & 0.0131 \\
\hline 20 & 77 & Fem & 1 & 0.47 & 0.451 & 0.0245 & 0.0241 \\
\hline 22 & 96 & Fem & I & 0.519 & 0.525 & 0.0306 & 0.0302 \\
\hline 27 & 166 & Fem & III & 0.604 & 0.616 & 0.0444 & 0.0463 \\
\hline 27 & 193 & Male & II & 0.598 & & 0.0583 & \\
\hline 29 & 212 & Male & II & 0.683 & & 0.0453 & \\
\hline 30 & 228 & Fem & II & 0.573 & 0.598 & 0.0459 & 0.0461 \\
\hline 32 & 310 & Male & III & 0.671 & 0.665 & 0.0677 & 0.0667 \\
\hline 33 & 338 & Fem & II & 0.641 & & 0.0562 & \\
\hline 42 & 778 & Fem & V & 0.714 & 0.714 & 0.0902 & 0.0875 \\
\hline
\end{tabular}

Table 6. Aethotaxis mitopteryx. Blood parameters. MCHC: mean corpuscular haemoglobin concentration; $\mathrm{MCH}$ : mean cellular haemoglobin content; $\mathrm{O}_{2}$-CC: carrying capacity for

$\mathrm{O}_{2} ; \mathrm{PO}_{2}$ and $\mathrm{PCO}_{2}$ : partial pressure of $\mathrm{O}_{2}$ and $\mathrm{CO}_{2} ; \mathrm{n}=11$

\begin{tabular}{|lccl|}
\hline Parameter & Unit & Mean & $\mathrm{SD}$ \\
\hline Haematocrit & $\%$ & 14.0 & 3.1 \\
Erythrocytes & $10^{12} \mathrm{I}^{-1}$ & 0.39 & 0.09 \\
Haemoglobin & $\mathrm{g} \mathrm{l}^{-1}$ & 27.8 & 4.7 \\
$\mathrm{MCHC}$ & $\mathrm{g} \mathrm{l}^{-1}$ & 1.98 .6 & - \\
$\mathrm{MCH}$ & $\mathrm{pg}$ & 71.3 & - \\
$\mathrm{O}_{2}-\mathrm{CC}$ in blood & $\mathrm{Vol} \%$ & 4.5 & 1 \\
$\mathrm{O}_{2}-\mathrm{CC}$ in cells & $\mathrm{Vol} \%$ & 27.4 & 3 \\
$\mathrm{pH}$ & 1 & 7.85 & 0.18 \\
$\mathrm{PCO}_{2}$ & $\mathrm{~mm} \mathrm{Hg}$ & 1.9 & 1.4 \\
$\mathrm{PO}_{2}$ & $\mathrm{~mm} \mathrm{Hg}$ & 43.5 & 8 \\
\hline
\end{tabular}

The values for number of red blood cells and haemoglobin concentration of Aethotaxis mitopteryx are at the lower end of the range known forAntarctic fishes. Everson \& Ralph (1968), Hureau et al. (1977) and Wells et al. (1980) report ranges for RBC of 0.4 to $1.2 \times 10^{12} \mathrm{l}^{-1}$ and for $[\mathrm{Hb}]$ of 21 to $64 \mathrm{~g} \mathrm{l}^{-1}$. The findings for $A$. mitopteryx are in good agreement with data for a close relative, Pleuragramma antarcticum, a holopelagic species with a sluggish mode of life (Kunzmann 1991).

Electrophoretic analysis of the haemolysate yielded only a single haemoglobin. This is unusual, since most other nototheniids have one major haemoglobin ( $\mathrm{Hb} 1$ ), accounting for 90 to $95 \%$ of the total content, accompanied by a second minor component ( $\mathrm{Hb} \mathrm{2,}$ about $5 \%$ of the total; di Prisco et al. 1990).

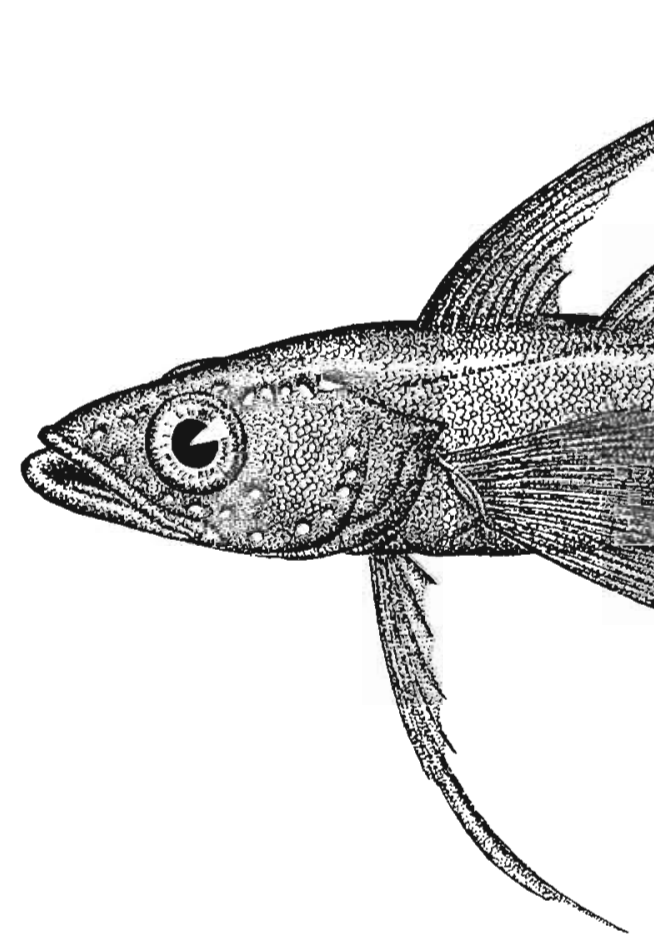

Fig. 4. Aethotaxis mitopteryx. Drawing based on 50 freshly caught specimens (including several large specimens of $>37 \mathrm{~cm} \mathrm{SL}$ ) and observations made during subsequent maintenance in the aquaria 


\section{DISCUSSION}

Aethotaxis mitopteryx is one of the lesser known high-Antarctic fish species. Below we try to depict its ecology and establish some links between its mode of life and oxygen transport characteristics.

\section{Abundance, distribution and growth}

In 14 hauls a total of 44 specimens were caught in the Weddell Sea (Table 2) in an area of about $28800 \mathrm{~km}^{2}$ (from $71^{\circ} \mathrm{S}, 12^{\circ} \mathrm{W}$ to $77^{\circ} \mathrm{S}, 36^{\circ} \mathrm{W}$, extending ca $60 \mathrm{~km}$ along the coastline). In comparison with other fish species caught during the same time, this is a very low density. According to Ekau (1990) the catches of Aethotaxis mitopteryx account for a biomass of 0.03 to $0.06 \mathrm{~kg} 30 \mathrm{~min}^{-1}$ (standardized fishing time $30 \mathrm{~min}$ ). Biomass values for other species in the same hauls $\left(\mathrm{kg} 30 \mathrm{~min}^{-1}\right.$ ) are in the range of 0.06 to 1.9 (ArtedidraConidae), 0.02 to 2.7 (Bathydraconidae), 0.03 to 35.7 (Channichthyidae) and 0.02 to 7.8 (Nototheniidae).

The 55 specimens from the Lazarev Sea (Table 2) were collected during 8 hauls in an area of about $10800 \mathrm{~km}^{2}$ (from $70^{\circ} 30^{\prime} \mathrm{S}, 7^{\circ} \mathrm{W}$ to $69^{\circ} 30^{\prime} \mathrm{S}, 9^{\circ} \mathrm{E}$, extending ca $30 \mathrm{~km}$ along the coastline). The biomass

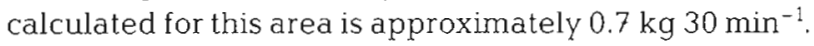
This is 10 times the value in the Weddell Sea and might indicate that this is a major distribution area of this species. Possible reasons for the higher abundance in the Lazarev Sea could be the availability of food due to high concentrations of zooplankton (Bathmann et al. 1992) and the absence of large breeding colonies of predators such as penguins and seals in the area.

In light of the current findings, the maximum total length and fresh weight values reported in the literature $(42 \mathrm{~cm}, 833 \mathrm{~g})$ must be increased to $48 \mathrm{~cm}$ and $850 \mathrm{~g}$, which also influences the growth parameters determined by Ekau (1988). However, growth of Aethotaxis mitopteryx is still extremely slow in comparison with other high-Antarctic species (Ekau 1988, Hubold 1991). According to Hubold (1991) slow growth in Antarctic fishes is not only due to the low temperature but is also a consequence of intrinsic energetic requirements. In fertile pelagic species, such as Pleuragramma antarcticum and A. mitopteryx, energy may be used for reproductive effort and the pelagic lifestyle and is not available for growth.

Based on fecundity investigations and larval abundance, Hubold (1992) assumed that the reproductive effort in Aethotaxis mitopteryx is high. Spawning seems to occur in late winter/early spring (Ekau 1991), which is in contrast to the more general pattern of autumn spawners with large yolky eggs. The regular occurrence of $A$. mitopteryx larvae is documented from catches on the shelf in the eastern and southeastern Weddell Sea (Piatkowski 1987). This is in strong contrast to the infrequent occurrence of adults in this area (see above). A. mitopteryx larvae are not reported from the Antarctic Peninsula, and only a single larva has been found in the Scotia Sea (Efremenko 1984), where a few adults have been caught (Table 2). We also have no data on A. mitopteryx larvae from the Lazarev Sea where the adults seem to be more abundant.

\section{Morphological features}

Due to the scarcity of well-preserved Aethotaxis mitopteryx specimens available to taxonomists we felt it necessary to make use of the good material we had and create a new drawing (Fig. 4), which closely represents the appearance of a live specimen. In the 'Results' section we therefore emphasized those morphological features which we think are not well dealt with in the previous descriptions. In the drawings from Hureau \& Fischer (1985) and Gon \& Heemstra (1990) some features, such as shape and thickness of fins, seem to be a result of the preservation procedure. Also, we think that the proportions of certain body features, such as the caudal fin peduncle, may slightly change with increasing age, and since the previous drawings represent younger specimens of less than $25 \mathrm{~cm} \mathrm{SL}$, we deliberately chose larger specimens. Moreover, the availability of more than 50 specimens excluded errors due to the sometimes destructive effects of catches by nets. Previous drawings have been based on only 1 or 2 specimens.

Several adaptations to a midwater lifestyle, such as reduction of bones (Andriashev 1987), weakly mineralized scales (DeVries \& Eastman 1981), extensive lipid deposits (Eastman \& DeVries 1982) and morphometric parameters such as gill raker, fin and body sizes (Ekau 1988), indicate a pelagic mode of life. Although Aethotaxis mitopteryx has also been caught by pelagic nets, its frequent occurrence in bottom trawls and Agassiz trawls (Table 2) suggests a rather benthopelagic lifestyle. In contrast to conclusions by Miller (1987), our observations from aquaria indicate that $A$. mitopteryx does not use the soft pelvic fins to sit at the bottom and that this species cannot withstand strong currents.

\section{Blood physiology and mode of life}

Our findings on Aethotaxis mitopteryx blood physiology differ distinctly from those for other Antarctic fish species. Its haematology is marked by very low values for the number of red blood cells, haemoglobin content and oxygen carrying capacity (Table 6). Haemo- 
globin of $A$. mitopteryx does not show a Root effect and only a weak Bohr effect (D'Avino et al. 1992). What do these features of $A$. mitopteryx blood suggest for its mode of life?

The well-known correlations among haemoglobin concentration, number of erythrocytes and activity (Coburn \& Fisher 1973, Larsson et al. 1976, Val et al. 1990) suggest a sluggish mode of life for this species. Similar results have been found for another pelagic and sluggish species of the same tribe, Pleuragramma antarcticum (Kunzmann 1991).

The functional properties of $A$. mitopteryx haemoglobin do not allow oxygen delivery to the tissues to be fine-tuned and indicate a limited scope of activity (D'Avino et al. 1992). Our own observations of behaviour and activity of specimens kept in aquaria confirm this assumption.

It is assumed that pelagic fishes of the high Antarctic need to buffer the extreme seasonality in ice regime, light and thus primary production, by incorporation of lipids (Eastman 1985, Hagen 1988) and an energy conserving mode of life. In A. mitopteryx and Pleuragramma antarcticum this is reflected in the slow growth of adults (Ekau 1988, Hubold 1992). Investigations on the 2 remaining tentatively pelagic species in the family Netotheniidae, Cryothenia peninsulae and Grozdarus svetovidovi, could further help elucidate this phenomenon.

\section{Conclusions}

In conclusion, we assume that Aethotaxis mitopteryx is a 'sit-and-wait' predator in the benthopelagial, which may undertake foraging trips into the pelagial. Adults seem to occur in the warm deep water and have exceptionally slow growth, whereas the energy spent for reproduction seems to be high. Larval abundance is high in the eastern and southeastern Weddell Sea, whereas adults seem to be more abundant in the Lazarev Sea. Spawning migrations are therefore very likely. Structural and functional features of the blood indicate a sluggish mode of life and a limited scope of activity. This together with a number of adaptations to life in the pelagial suggests low energy requirements. For a thorough understanding of their physiological adaptations to life in the water column more investigations on all 4 species of the tribe Pleuragrammiini are necessary.

Acknowledgements. We thank W. Ekau, A. Wöhrmann and G. di Prisco for their contribution of data. Special thanks are due to the crew of RV 'Polarstern', who made the collection of data possible under difficult conditions. Part of this work was financed by the Deutsche Forschungsgemeinschaft and the European Science Foundation.

\section{LITERATURE CITED}

Andersen, N. C. (1984). Genera and subfamilies of the family Nototheniidae from the Antarctic and Sub-Antarctic Steenstrupia 10(1): 1-34

Andriashev, A. P. (1987). A general review of the Antarctic bottom fish fauna. In: Kullander, S. O., Fernholm, B. (eds.) Proc. 5th Cong. Eur Ichthyol., Stockholm 1985. Department of Vertebrate Zoology, Museum of Natural History, Stockholm, p. 357-372

Bathmann, U., Schulz-Baldes, M., Fahrbach, E., Smetacek, V., Hubberten, H.-W. (1992). Die Expeditionen ANTARKTIS IX/1-4 des Forschungsschiffes 'Polarstern' 1990/91. Ber. Polarforsch. 100: 1-403

Coburn, C. B., Fischer B. A. (1973). Red blood cell hematology of fishes: a critique of techniques and a compilation of published data. J. mar. Science 2(2): 37-58

D'Avino, R., Fago, A., Kunzmann, A., di Prisco, G. (1992). The primary structure and oxygen binding properties of the single haemoglobin of the high-Antarctic fish Aethotaxis mitopteryx DeWitt. Polar Biol 12: 135-140

DeVries, A. L., Eastman, J. T. (1981). Physiology and ecology of notothenioid fishes from the Ross Sea. J R. Soc. N.Z. $11(4): 329-340$

DeWitt, H. H. (1962). A new Antarctic notothenioid fish with notes on two recently described Nototheniiforms. Copeia 4: $826-833$

DeWitt, H. H. (1970). The character of the midwater fish fauna of the Ross Sea, Antarctica. In: Holdgate, M. W. (ed.) Antarctic ecology, Vol. 1. Academic Press, London, p. 305-314

di Prisco, G., D'Avino, R., Camardella, L., Caruso, C., Romano, M., Rutigliano, B. (1990). Structure and function of haemoglobin in Antarctic fishes and evolutionary implications. Polar Biol. 10: 269-274

di Prisco, G., Tamburrini, M., Kunzmann, A. (in press). Fisheries biology and structure and function of fish haemoglobins (ANT X/3 March-May 1992). Ber. Polarforsch.

Eastman, J. T (1985). The evolution of neutrally buoyant Notothenioid fishes: their specializations and potential interactions in the Antarctic marine food web. In: Siegfried, W. R, Condy, P. R., Laws, R. M. (eds.) Antarctic nutrient cycles and food webs. Springer, Berlin, p. 430-436

Eastman, J T., DeVries, A. L. (1982). Buoyancy studies of notothenioid fishes in McMurdo Sound. Antarctica. Copeia 1982: 385-393

Efremenko, V. N. (1984). Larvae of the family Nototheniidae from the Scotia Sea. J. Ichthyol. 24(1): 34-43

Ekau, W. (1988). Ökomorphologie nototheniider Fische aus dem Weddellmeer, Antarktis. Ber. Polarforsch. 51: 39-134

Ekau, W. (1990). Demersal fish fauna of the Weddell Sea. Antarct. Sci. 2(2): 129-137

Ekau, W. (1991). Reproduction in high Antarctic fishes (Notothenioidei). Meeresforsch. 33: 159-167

Everson, I. (1977). The living resources of the Southern Ocean. FAO GLO/SO/77/1. F.A.O., Rome

Everson, I., Ralph, R. (1968). Blood analyses of some Antarctic fish. Br. Antarct. Surv. Bull. 15: 59-62

Gerasimchuk, V. V., Piotrovskiy, A. S. (1981). A find of a rare fish Aethotaxis mitopteryx DeWitt 1962 (Nototheniidae, Osteichthyes) in the Indian Ocean sector of the Antarctic. J. Ichthyol. 20(4): 138-140

Gon, O., Heemstra, P. C. (eds.) (1990). Fishes of the Southern Ocean. J. L. B. Smith Institute of Ichthyology, Grahamstown, p. 283-284

Hagen, W. (1988). Zur Bedeutung der Lipide im 
Antarktischen Zooplankton. Ber. Polarforsch. 49: 1-129

Hallmann, L. (1980). Klinische Chemie und Mikroskopie. Thieme, Stuttgart

Hecht, T (1987). A guide to the otoliths of Southern Ocean fishes. S. Afr. J. Antarct. Res. 17(1): 36-38

Hellmer, H. H., Bersch, M. (1985). The Southern Ocean. Ber. Polarforsch. 26: 1-115

Hempel, G. (1985). Die Expedition Antarktis III mit FS 'Polarstern' 1984/85. Ber. Polarforsch. 25: 1-209

Hubold, G. (1991). Ecology of notothenioid fishes in the Weddell Sea. In: di Prisco, G., Maresca, B., Tota, B. (eds.) Biology of Antarctic fishes. Springer, Berin, p. 3-22

Hubold, G. (1992) Zur Ökologie der Fische im Weddellmeer. Ber. Polarforsch. 103: 1-157

Hubold, G., Ekau, W. (1987). Midwater fish fauna of the Weddell Sea, Antarctica. In: Kullander, S. O., Fernholm, B. (eds.) Proc. 5th Cong. Eur. Ichthyol., Stockholm 1985. Department of Vertebrate Zoology, Museum of Natural History, Stockholm, p. 391-396

Hureau, J. C., Balguerias, E., Duhamel, G., Kock, K.-H., Ozouf-Costaz, C. (1990). Fish fauna of the eastern Weddell Sea. Ber. Polarforsch. 68: 130-138

Hureau, J. C., Fischer, W. (eds.) (1985). FAO identification sheets for fishery purposes. Southern Ocean, Vol. II F.A.O., Rome, p. $334-335$

Hureau, J. C., Petit, D., Fine, J. M., Marneux, M. (1977). New cytological, biachemical, and physiological data on the colorless blood of the Channichthyidae (Pisces, Teleosteans, Perciformes). In: Llano, G. A. (ed.) Adaptations within Antarctic ecosystems. Gulf Publishing Co., Houston, p. 459-477

Kooyman, G. L. (1963). Erythrocyte analysis of some Antarctic fishes. Copeia 1963: 457-458

Kotlyar, A. N. (1979). A new discovery of rare fish species, Aethotaxis mitopteryx (Fam. Nototheniidae) and Pseudojcichthys australis (Fam. Centrolophidae) in the Southern Atlantic. Vopr. Ikhtiol. 18(2) (in Russian, translation in J. Ichthyol 1979: 324-326)

Kunzmann, A. (1991). Blood physiology and ecological consequences in Weddell Sea fishes. Ber. Polarforsch. 91: 1-79

Kunzmann, A., di Prisco, G. (1990). On the blood physiology of Weddell Sea fishes. In: Second Int. Conf. Biol. Antarct. Fishes, Ravello, 30.5-1.6.90. IIGB Press, Naples, p. 65-66

Larsson, A., Johansson-Sjöbeck, M. L., Fänge, R. (1976). Comparative study of some hematological and biochemical blood parameters in fishes from the Skagerrak. J. Fish Biol. 9: 425-440

Love, R. M. (1980). The chemical biology of fishes, Vol. 2, Advances 1968-77. Academic Press, London

Miller, R. G. (1987). Origins and pathways possible for the

This article was submitted to the editor fishes of the Antarctic Ocean. In: Kullander, S. O., Fernholm, B. (eds.) Proc. 5th Cong. Eur. Ichthyol., Stockholm 1985. Department of Vertebrate Zoology. Museum of Natural History, Stockholm, p. 373-380

Permitin, Y Y (1966). New data on the species composition and distribution of fish of the Scotia Sea in the Antarctic, Comm. I. Vopr. Ikhtiol. 6(3): 40 (in Russian)

Permitin, Y Y (1969). New data on the species composition and distribution of fish of the Scotia Sea in the Antarctic, Comm. Il. Vopr. Ikhtiol. 9(2): 55 (in Russian, translation in J. Ichthyol. 1969: 167-181)

Piatkowski, U. (1987). Zoogeographische Untersuchungen und Gemeinschaftsanalysen an antarktischem Makroplankton. Ber. Polarforsch. 34: 78-84

Riggs, A. (1970). Properties of fish hemoglobins. In: Hoar, W. S., Randall, D. J. (eds.) Fish physiology, Vol. IV. Academic Press, London, p. 209-246

Schnack-Schiel, S. (1987). Die Winter-Expedition mit FS 'Polarstern' in die Antarktis (ANT V/1-3). Ber. Polarforsch. 39: 1-277

Takahashi, M. (1982). Food of Antarctic demersal fishes off South Shetland. Unpublished lecture. National Institute of Polar Research, 9-10 Kaga 1-chome, Itabashi-ku, Tokyo 173, Japan

Townsend, D. W. (1980). Microstructural growth increments in some Antarctic fish otoliths. Cybium 3(8): 17-22

Trunov, I. A. (1985). Species composition and biology of fishes from shelf and slope of the Antarctic continent (in Lazarev Sea). In: Yakovlev, V. N. (ed.) Complex study of the bioproductivity of the Southern Ocean, Vol. II. Trudy VNIRO, Moscow, p. 316-324 (in Russian)

Val, A. L., Almeida-Val, V. M. F., Affonso, E. G. (1990). Adaptive features of Amazonian fishes: haemoglobins, haematology, intraerythrocytic phosphates and whole blood Bohr effect of Pterygolichthys multiradiatus (Siluriformes). Comp. Biochem. Physiol. 97B(3): 435-444

Wells, R. M., Ashby, M. D., Duncan, S. J., Macdonald, J. A (1980). Comparative study of the erythrocytes and haemoglobins in nototheniid fishes from Antarctica. J. Fish Biol. 17: $517-527$

Wells, R. M. G., Grigg, G. C., Beard, L. A., Summers, G (1989). Hypoxic responses in a fish from a stable environment: blood oxygen transport in the Antarctic fish Pagothenia borchgrevinki. J. exp. Biol. 141: 97-111

Williams, R. (1987). Australian Antarctic research program. Unpublished field report. Australian Anatarctic Division, Channel Highway, 7050 Kingston, Tasmania, Australia

Wöhrmann, A. P. A., Zimmermann, C. (1992). Comparative investigations on the fish fauna of the Weddell Sea and the Lazarev Sea. Ber. Polarforsch. 100: 208-222

Manuscript first received: June 12, 1992

Revised version accepted: October 1, 1992 